\title{
Diskriminasi Pendidikan Masyarakat Terpencil
}

\author{
Firdaus $^{1}$, Sulfasyah ${ }^{2}$, Hanis Nur ${ }^{3}$ \\ ${ }^{1}$ Pendidikan Sosiologi, Universitas Muhammadiyah Makassar \\ Email: firdaus@unismuh.ac.id \\ Pendidikan Sosiologi, Universitas Muhammadiyah Makassar \\ Email: sulfasyah@gmail.com \\ ${ }^{3}$ Pendidikan Sosiologi, Universitas Muhammadiyah Makassar \\ Email: hanisnur@gmail.com
}

\begin{abstract}
The research entitled "Discrimination in remote community education (Case study of Buntu Mondong village, Enrekang District" aims to determine the existence of education discrimination in remote communities in Buntu Mondong village, Enrekang District, with qualitative research methods. This research was conducted by observing the condition of the school which includes the condition of students, teachers and infrastructure as well as the conditions in the surrounding environment which also influence the quality of education. The data has been collected, and then analyzed descriptively. The results of the study illustrate the occurrence of educational discrimination in SDN NO 79 Gura. Educators and infrastructure facilities that cause education in the area to be not optimal. The available educators lack excellence in midwives and have low quality so that what is given to their students is also mediocre. a Less quality educator, Infrastructure that supports the learning process teaches very little, so the learning process often experiences obstacles. By that, especially for the government and education implementers should increase attention to education in remote areas, especially in SDN NO. 79 Gura.
\end{abstract}

Keywords: Discrimination, Education, Remote Communities

\begin{abstract}
Abstrak. Penelitian dengan judul "Diskriminasi pendidikan masyarakat terpencil (Study kasus masyarakat desa Buntu Mondong, Kecamatan Buntu Batu, Kabupaten Enrekang" ini bertuj uan untuk mengetahui terj adinya diskriminasi pendidikan masyarakat terpencil di desa Buntu Mondong Kecamatan Buntu Batu Kabupaten Enrekang, dengan metode penelitian Kualitatif. Penelitian ini dilakukan dengan mengamati Kondisi Sekolah yang meliputi keadaan siswa, guru dan sarana prasarana serta keadaan di lingkungan sekitar yang turut mempengaruhi kualitas pendidikan. Data yang telah dikumpulkan, kemudian dianalisa secara deskriftif. Hasil penelitian menggambarkan tentang terjadinya diskriminasi pendidikan di SDN NO. 79 Gura, yaitu diskriminasi tenaga pendidik dan sarana prasaran yang menyebabkan Pendidikan di daerah tersebut tidak maksimal. Tenaga pendidik yang tersedia kurang memiliki keunggulan di bidannya dan memiliki kualitas yang rendah sehingga apa yang diberikan untuk anak didiknya j uga pas-pasan. Selain Tenaga Pendidik yang kurang berkualitas, Sarana Prasarana yang menunjang proses belaj ar mengaj ar sangat sedikit, sehingga proses belaj ar mengaj ar seringkali mengalami hambatan. Olehnya itu, Khusunya bagi pemerintah dan pelaksana pendidikan harus lebih meningkatkan perhatian terhadap Pendidikan di daerah Terpencil, khusunya di SDN NO 79 Gura.
\end{abstract}

Kata Kunci : Diskriminasi, Pendidikan, Masyarakat Terpencil

\section{PENDAHULUAN}

Manusia pada hakikatnya diciptakan oleh Tuhan sebagai makhluk terhormat dan mulia. Oleh karena itu, perlindungan dan penghormatan terhadap manusia merupakan 
tuntutan yang wajib dilaksanakan oleh seluruh umat manusia terhadap sesamanya tanpa terkecuali. Sejak dilahirkan manusia telah memiliki hak asasi. Hak asasi tersebut merupakan hak dasar dari Tuhan yang wajib dihormati, dijunjung tinggi, dan dilindungi oleh negara, hukum, pemerintahan, dan setiap orang demi kehormatan serta perlindungan harkat dan martabat manusia.

Indonesia merupakan negara yang paling banyak memiliki ragam budaya dibandingkan dengan negara lainnya . Tidak hanya itu, di Indonesia juga terdapat perbedaan atas ras, suku, agama, dan adat-istiadat yang merupakan ciri khas daerah masing-masing. Namun demikian, perbedaan itulah yang mengantarkan Indonesia pada persatuan dan kesatuan.

Dengan adanya UUD 1945 sebagai dasar negara, segala hal mengenai perbedaan itu terangkum didalamnya dan menjadi tolok ukur bagi kesejahteraan warga negara sehingga diharapkan tidak ada batas antara kelompok satu dengan yang lainnya dan tidak ada yang merasa di anak-tirikan oleh pemerintah atau merasa menjadi kaum minoritas. Hal ini tercantum dalam UUD 1945 pasal 28 C ayat 1 yang berbunyi, "Setiap orang berhak mengembangkan diri melalui pemenuhan kebutuhan dasarnya, berhak mendapat pendidikan dan memperoleh manfaat dari ilmu pengetahuan dan teknologi, seni dan budaya, demi meningkatkan kualitas hidupnya dan demi kesejahteraan umat manusia".

Dasar negara ini menekankan tiap orang berhak untuk mendapatkan segala hal yang menjadi tumpuan, penunjang ataupun alat dalam meningkatkan kualitas hidupnya dan demi kesejahteraannya tanpa harus merugikan orang lain dan lingkungannya. Hal yang menjadi penentu tingkat kualitas kehidupan dan kesejahteraan salah satunya adalah tingkat pendidikan. Melalui pendidikan seseorang dapat mendapatkan ilmu pengetahuan dan segala hal yang dapat membantunya meningkatkan kualitas hidupnya. Memperoleh pendidikan yang layak merupakan hak tiap warga negara dan negara berkewajiban memberikan secara merata dan seimbang kepada tiap warganya tanpa terkecuali.

Namun pada kenyataannya, pemerintah belum memberikan pendidikan yang layak dan berkualitas kepada setiap warganya. Di daerah perkotaan, pendidikan yang berkualitas 
semakin sulit dijangkau oleh masyarakat menengah ke bawah. Sedangkan di daerah pelosok, permasalahan yang terjadi sering kali kurangnya tenaga pendidikan dan fasilitas pendidikan. Hal ini merupakan contoh bentuk dari pelanggaran Hak Asasi Manusia terhadap kaum minoritas atau terjadinya diskriminasi terhadap masyarakat menengah kebawah dalam bidang pendidikan.

Diskriminasi merujuk kepada pelayanan yang tidak adil terhadap individu tertentu, di mana layanan ini dibuat berdasarkan karakteristik yang diwakili oleh individu tersebut. Diskriminasi merupakan suatu kejadian yang biasa dijumpai dalam masyarakat manusia, ini disebabkan karena kecenderungan manusian untuk membeda-bedakan yang lain. Ketika seseorang diperlakukan secara tidak adil karena karakteristik suku, antar golongan, kelamin, ras, agama dan kepercayaan, aliran politik, kondisi fisik atau karateristik lain yang diduga merupakan dasar dari tindakan diskriminasi. Bentuk diskriminasi ada 2, yaitu:

1. Diskriminasi langsung, terjadi saat hukum, peraturan atau kebijakan jelas jelas menyebutkan karakteristik tertentu, seperti jenis kelamin, ras, dan sebagainya, dan menghambat adanya peluang yang sama.

2. Diskriminasi tidak langsung, terjadi saat peraturan yang bersifat netral menjadi diskriminatif saat diterapkan di lapangan.

Hakikat pendidikan adalah proses peradaban dan pemberadaban manusia. Pendidikan adalah aktivitasi semua potensi dasar manusia melalui interaksi manusia dewasa dengan yang belum dewasa. Pendidikan adalah proses kemanusiaan dan pemanusiaan sejati, dengan atau penyengajaan. Pendidikan adalah Proses pemartabatan manusia menuju puncak optimasi potensi kognitif, afektif, dan psikomotorik yang dimilikinya. Pendidikan adalah proses membimbing, melatih, dan memandu manusia terhindar atau keluar dari kebodohan dan pembodohan. Pendidikan adalah metamorfosis perilaku menuju kedewasan sejati. Pendidikan juga dapat didefenisikan sebagai proses elevasi yang di lakukan secara non diskriminasi, dinamis, dan intensif menuju kedewasan individu, dimana prosesnya di lakukan secara kontinue dengan sifat yang adaptif dan nirlimitid atau tiada akhir.

Berdasarkan pengamatan selama ini pendidikan yang telah dilaksanakan di Sekolah Dasar di kabupaten Enrekang khususnya di desa Buntu Mondong Kecamatan Buntu Batu masih terdapat banyak kekurangan baik dari segi sarana maupun prasarana hal itu di 
sebabkan karena adanya sebuah sistem yang tidak berjalan sebagai mana mestinya di mana telah terjadi diskriminasi pendidikan atau dengan kata lain ketidak meratan pendidikan dalam artian pendidikan yang terlaksana di sekolah- sekolah tersebut belum seperti sekolahsekolah yang ada di kota-kota baik yang ada di kota madya maupun yang ada di tingkat provinsi maupun yang ada di pusat.

Selama ini pendidikan yang telah berlangsung kurang maksimal atau sangat jauh dari yang semestinya itu dikarenakan pemerintah setempat menganggap bahwa ketidak maksimalan pendidikan yang terselenggara di sebabkan karena letaknya yang jauh dan di samping itu sangat sulit di jangkau oleh kendaraan, sehingga pemerintah seakan-akan memandang sebelah mata.

Untuk menanggapi ungkapan di atas maka diperlukan suatu cara tentang bagaimana pemerintah setempat dan pemerintah pusat bisa saling bekerja sama dalam melaksanakan pendidikan yang layak sehingga para siswa/siswi bisa juga mengenyam pendidikan yang layak dan sebagaimana mestinya sehingga tujuan dari pendidikan dan UUD bisa tercapai dan terlaksana yakni bagaimana menyeratakan pendidikan baik yang ada di pusat maupun yang ada di daerah atau desa bisa mencerdaskan kehidupan anak bangsa secara menyeluruh bukan secara sepi hak.

\section{LANDASAN TEORI}

Secara formal, pengertian diskriminasi di atur di dalam UU No. 39 Tahun 1999 tentang hak asasi manusia pasal 1 ayat (3). Undang -Undang tersebut menyatakan, Diskriminasi adalah setiap pembatasan, pelecehan, atau pengucilan yang langsung ataupun tak langsung di dasarkan pada pembedaan manusia atas dasar agama, suku, ras, etnik, kelompok, golongan, status sosial, status ekonomi, jenis kelamin, bahasa, keyakinan, politik, yang berakibat pengurangan, penyimpangan, atau pengapusan pengakuan, pelaksanaan, atau pengguna hak asasi manusia dan ke bebebasan dasar dalam kehidupan baik individu maupun kolektif dalam bidang politik, ekonomi, hukum, sosial, budaya dan aspek kehidupan lainnya. (KEPRES,1999) 
Adapun jenis diskriminasi yang terjadi di SD Gura yaitu diskriminasi tenaga pendidik serta diskriminasi sarana dan prasarana. Seperti yang kita ketahui bahwa setiap tahun pemerintah selalu melakukan upaya untuk peningkatan/perbaikann kualitas pendidikan sehingga output dari pendidikan tersebut memiliki daya saing dan siap untuk dipekerjakan. Namun, pada kenyataannya masih terjadi diskriminasi pendidikan masyarakat terpencil di Desa Buntu Mondong kecamatan Buntu Batu Kabupaten Enrekang, yang mengakibatkan pendidikan tidak maksimal dan jauh dari standar seperti yang terjadi di perkotaan.

Pertama, diskriminasi tenaga pendidik; seperti yang kita ketahui bersama bahwa guru atau tenaga pendidik adalah penopang yang paling utama dan mendasar bagi peningkatan kualitas pendidikan. Namun, yang terjadi pada Sekolah Dasar Gura, disamping tenaga pendidik yang kurang, guru yang berpangkat sebagai PNS kadang lalai dari tugasnya. Mereka menolak untuk dimutasi ketempat yang terpencil, dengan alasan terlalu jauh. Tanpa mereka sadari siswa siswi menjadi korban, dimana mereka tidak mendapatkan pendidikan yang layak sebagai mana mesti nya, hal ini karena sebagian besar tenaga pendidik hanya berstatus honorer. Hal ini bertolak belakang dengan upaya pemerintah untuk memperbaiki mutu pendidikan dari tahun ke tahun. Kasus seprti ini disamping merugikan peserta didik juga merugikan pemerintah.

Kedua, diskriminasi sarana dan prasarana: sarana dan prasaran merupakan salah satu penopang dari peningkatan kualitas pedidikan itu sendri. Namun, seiring dengan kurang memadai dan jauh dari standar yang ada, gedung sekolah yang tidak kondusip serta fasilitas belajar yang kurang memadai. Disamping gedung sekolah yang kurang memadai, keadaan ruang belajar juga kurang memungkinkan, seperti tidak adanya pendingin ruangan kipas angin atau AC yang menyebabkan suasana belajar pada siang hari kurang maksimal. Kita telah mengetahui bahwa dalam proses pembelajaran ruangan kelas merupakan komponen yang sangat penting demi tercapainya proses belajar mengajar yang efektif. Selain itu, sekolah tidak dilengkapi dengan lab komputer sedangkan siswa siswi sudah harus belajar TIK (Teknologi Informasi dan Komunikasi) sesuai dengan yang dianjurkan oleh pemerintah demi untuk menciptakan output pendidikan yang tidak buta teknologi dalam rangka menciptakan lulusan yang berkualitas. Namun inilah realitas yang terjadi pada 
pendidikan masyarakat terpencil Desa Buntu Mondong Kecamatan Buntu Batu Kabupaten Enrekang.

Diskriminasi megakibatkan pengurangan, penyimpangan, atau penghapusan pengakuan, pelaksanaan atau penggunaan hak asasi manusia dan kebebasan dasar dalam kehidupan, baik individual maupun kolektif dalam bidang politik, ekonomi, hukum, sosial, budaya dan aspek kehidupan lainnya. Seperti yang telah ditegaskan dalam pasal 281 ayat 2 UUD NKRI 1945 bahwa "Setiap orang berhak bebas dari perlakuan yang bersifat diskriminatif atas dasar apapun dan berhak mendapatkan perlindungan terhadap perlakuan yang bersifat diskriminatif itu". Sangat jelas sekali bahwa setiap orang mendapat perlindungan saat dia mendapat perlakuan diskriminasi. Meskipun begitu diskriminasi masih terjadi diberbagai belahan dunia, dan prinsip non diskriminasi harus mengawali kesepakatan antar bangsa untuk dapat hidup dalam kebebasan, keadilan, dan perdamaian.

Mahalnya biaya pendidikan merupakan salah satu penyebab banyaknya jumlah penduduk Indonesia yang tidak dapat menikmati pendidikan. Berdasarkan data kementrian pendidikan nasional, jumlah siswa smp sederajat terdapat sekitar 12 juta siswa yang tidak bersekolah. Jumlah tersebut masih jumlah siswa SMP, belum lagi terdata siswa SD, SMA dan Mahasiswa serta anak-anak yang tidak pernah mengenyam pendidikan sama sekali. Tentunya jika kita melihat data jumlahnya maka akan sangat memilukan. Masalah biaya pendidikan haruslah kita pandang dengan mata terbuka, tanpa menyembunyikan realitas yang terjadi. Oleh Karena itu, berbicara tentang biaya pendidikan pastinya tidak akan habishabisnya dan tidak akan terselesaikan dengan semudah membalikan telapak tangan. Hal tersebut dikarenakan mengingat masih banyaknya masyarakat miskin di Negeri tercinta ini yang belum dapat menikmati pendidikan. Meskipun biaya pendidikan dianggarkan sebesar 20 persen dari APBN dan ditambahkan lagi dari APBD, namun masyarakat masih harus berjuang dalam mengisi perut sejengkalnya dan untuk menikmati pendidikan tentunya masih hanya mimpi. (KOMPAS,2010). 


\section{METODE PENELITIAN}

Penelitian mengenai ini merupakan penelitian deskriktif dengan pendekatan kualitatif, di mana peneliti menggunakan metode penelitian kualitatif untuk mengetahui dampak yang diti mbulkan dari diskri mi nasi pendidikan masyarakat terpencil masyarakat desa Buntu Mondong Kecamatan Buntu Batu Kabupaten Enrekang yang sesuai dengan rumusan masalah dan tujuan penelitian. Dalam penelitian ini jenis data yang di kumpulkan terdiri atas data primer, yaitu berupa kata-kata dan tindakan/peri laku orang־orang yang diamati dari hasil wawancara serta observasi, sedang kan data-data sekunder yang didapatkan berupa dokumen tertulis, gambar dan foto-foto. Analisa ini dilakukan dengan cara menyusun, mereduksi data, menyajian dan memberikan verifikasi untuk penarikan kesimpulan. Sedangkan teknik keabsahan data melalui triangulasi sumber, triangulasi teknik, dan triangulasi waktu.

\section{PEMBAHASAN}

Penelitian yang telah dilakukan untuk mengetahui terjadinya diskriminasi pendidikan masyarakat terpencil “(Study Kasus Masyarakat Desa Buntu Mondong Kecamatan Buntu Batu Kabupaten Enrekang)", khusunya di SDN NO. 79 Gura dilakukan dengan metode kualitatif dan dianalisa secara deskriftif, untuk mendapatkan data tentang pendidikan di SDN NO. 79 Gura dan disertai dengan gambar. Dari hasil penelitian yang dilaksanakan di SDN NO. 79 Gura sangat nampak jelas tentang adanya diskriminasi di dunia pendidikan, yakni diskriminasi guru dan sarana prasaran. Sarana prasarana Di SDN NO. 79 Gura, Jika dibandingkan dengan sekolah di perkotaan, sekolah model atau sekolah unggulan sangat jelas berbeda. Ini dapat dilihat dari berlimpahnya fasilitas sekolah unggulan yang teletak di pusat-pusat kota saja, sedangkan di daerah terpencil khususnya SDN NO. 79 Gura, jangankan memiliki fasilitas yang mewah, ruangan belajar hanya sederhana dan di lengkapi dengan fasilitas seadanya saja.

Pada kenyataannya, pembangunan fisik sekolah-sekolah di wilayah perkotaan terus menjamur seiring dengan dikeluarkannya dana BOS (Bantuan Operasional Sekolah) oleh pemerintah. Sayangnya perhatian pemerintah tentang pendidikan yang disalurkan lewat dana BOS tersebut tidak begitu nyata dirasakan dampaknya oleh masyarakat atau sekolah- 
sekolah di daerah pedalaman atau daerah terpencil. Serta kualitas pengajarnya yang paspasan menjadi salah satu faktor penyebab pendidikan di daerah terpencil terkesan tertinggal. Sehingga kemajuan pendidikan di Indonesia hanya terpusat di daerah perkotaan sedangkan di daerah terpencil kurang diperhatikan.

Di sisi lain, kita bisa melihat bagaimana pemerintah mendiskriminasikan juga untuk anak-anak di daerah yang jumlah peserta didiknya sedikit dengan memberikan bantuan jumlah guru yang sedikit juga. Terkait dengan masalah pemenuhan tenaga pendidik, pemerintah kita (melalui dinas pendidikan) sebenarnya secara khusus telah berusaha melakukan pemenuhan melalui penempatan guru-guru Pegawai Negeri Sipil (PNS) baru yang di tempatkan di daerah tertinggal atau terpencil. Akan tetapi, fakta di lapangan menunjukkan bahwa banyak guru yang enggan mengajar di daerah terpencil dengan beragam alasan. Menurut Berg (2006) dalam Riza Diah, AK dan Pramesti Pradna P., salah satu faktor yang menyebabkan keengganan para guru untuk mengajar di daerah terpencil atau tertinggal adalah letak sekolah yang sulit dijangkau. Alasan berikutnya adalah minimnya fasilitas dan hiburan.

Masalah yang tidak kalah menyita perhatian dalam pendidikan terutama di daerah terpencil adalah masalah kualitas guru. Tuntutan mengajar seorang guru di daerah terpencil lebih berat bila dibandingkan tuntutan guru yang mengajar di daerah perkotaan. Hambatan ini dipicu oleh masalah minimnya sarana dan prasarana penunjang proses pembelajaran di daerah terpencil. Selain kurang diperhatikannya nasib guru di daerah terpencil, sistem perekrutan guru di daerah terpencil juga kurang baik. Biasanya guru yang terdapat di daerah terpencil bukanlah seseorang yang ahli di bidangnya. Seringkali guru di daerah pedalaman adalah seseorang dengan ilmu dan kemampuan mengajar yang seadanya. Hal ini biasanya disebabkan karena guru yang direkomendasikan untuk mengajar tidak ahli di bidangnya sehingga proses pembelajaran tidak berjalan maksimum.

Keadaan lingkungan dan kondisi masyarakat di daerah terpencil, khususnya di Gura, Desa Buntu Mondong Kecamatan Buntu Batu merupakan salah satu penghambat berlangsungnya proses pendidikan. Di daerah tersebut belum banyak adanya pembangunan seperti di daerah perkotaan, yaitu pembangunan jalan (perbaikan jalan), sehingga alat 
transportasi sulit menjangkaunya. Belum lagi kondisi jalan yang berkelok-kelok dan tanjakan yang memperburuk kondisi untuk menjangkau Sekolah tersebut.

Berbagai dampak dari masalah muncul seiring dengan memanasnya masalah pendidikan yang dialami oleh daerah terpencil. Dampak dari masalah-masalah tersebut antara lain, kemajuan mutu pendidikan di suatu daerah terpencil akan terhambat. Mutu pendidikan di daerah terpencil tidak akan pernah sama dengan mutu pendidikan di daerah perkotaan selama masalah-masalah pendidikan di daerah terpencil belum dapat teratasi. Selain itu, masalah-masalah tersebut menyebabkan tertinggalnya pembangunan suatu daerah dengan daerah lainnya. Seperti yang telah disebutkan bahwa, kemajuan pendidikan di suatu daerah/negara

Masalah pendidikan seharusnya dilakukan dengan cara yang terpisah-pisah. Pembenahan dalam fasilitas, staft pengajar, daerah terpencil, dan lain-lain harus ditempuh dengan langkah yang menyeluruh. Tidak hanya memperhatikan dari kenaikan anggaran saja, tapi semuanya harus diperhatikan. Sebab akan percuma saja jika anggaran yang diberikan tinggi tapi pencapaian pembenahan terhadap fasilitas tidak terlaksana, maka akan menimbulkan masalah. Sangat di sayangkan sumber daya manusia dan mutu pendidikan menjadi rendah.

Sekolah haruslah menyediakan fasilitas belajar yang memadai dan baik agar siswa merasa nyaman dalam melaksanakan proses belaj ar mengaj ar serta agar kedepannya mampu menghasilkan pribadi yang berkualitas baik mutu, mental, dan kepribadian. Selain itu kelengkapan fasilitas belajar bagi siswa juga berguna untuk melatih kemandirian siswa dalam memperoleh bahan ajar tambahan selain dari guru pengajar ataupun buku panduan yang mereka punya. Siswa juga bisa mengembangkan daya kreativitas dan inovatifnya melalui fasilitas-fasilitas belajar yang terdapat di sekolah sehingga siswa mampu menjadi pribadi yang kreatif dan inofatif.

Selain itu, perlu dilakukan pengawasan terhadap berbagai jenis bantuan yang akan digunakan untuk memperbaiki sarana dan prasarana, kualitas guru dan penunjang pendidikan lainnya. Hal ini bisa direalisasi kan dengan semangat otonomi daerah, sehingga 
pengawasan pemerintah terhadap pendidikan di daerah-daerah terpencil lebih optimal. Oleh karena itu, tidak hanya pemerintah yang harus berperan dalam memajukan pendidikan di daerah terpencil, namun peran serta dan kesadaran masyarakat akan pentingnya pendidikan dalam suatu kehidupan juga menjadi peran penting dalam memajukan pendidikan dan selanjutnya pembangunan di suatu daerah, terutama daerah terpencil.

\section{KESIMPULAN}

Mayoritas guru yang terdapat di daerah terpencil bukanlah seseorang yang ahli di bidangnya, selain itu, guru dari aspek kebutuhan, guru juga masi jau dari kesejahteraan. Pemerintah belum mampuh memenuhi kebutuhan hidup keluarga dan menjami keseharian para guru. Dampak dari hal tersebut membuat guru belum professional dalam mengajar. Tenaga pendidik yang tersedia kurang memiliki keunggulan di bidannya dan memiliki kualitas yang rendah sehingga apa yang diberikan untuk anak didiknya j uga pas-pasan. Selain Tenaga Pendidik yang kurang berkualitas, Sarana Prasarana yang menunjang proses belaj ar mengaj ar sangat sedikit, sehingga proses belaj ar mengaj ar seringkali mengalami hambatan. Olehnya itu, Khusunya bagi pemerintah dan pelaksana pendidikan harus lebih meningkatkan perhatian terhadap Pendidikan di daerah Terpencil, khusunya di SDN NO 79 Gura

\section{DAFTAR PUSTAKA}

Adisasmita, R. (2006). Membangun Desa Pariwisata. Graha Ilmu: Makassar.

Arsyad, L. Dkk. (2011). Strategi Pembangunan Pedesaan Berbasis Lokal.UPP STIM YKPN: Yogyakarta

Aunurrahman, (2011). Belajar dan Pembelajaran. Alfabeta : Bandung

Danim, S. (2011). Pengantar Kependidikan, Landasan Teori dan 234 Metafora Pendidikan. Alfabeta: Bandung.

Emzir. (2007). Metodologi Penelitian Pendidikan. RajaGrafindo Persada: Jakarta FKIP. (2007). Etika Propesi Keguruan. Fakultas Keguruan dan Ilmu Pendidikan Universitas Muhammadiyah Makassar

Hanis, Nur, dkk. (2013). Manajemen Kelas. Lembaga Perpustakaan Universitas Muhammadiyah Makassar : Makassar KEPRES,(1999). Undang-Undang Republik Indonesia Nomor 39 Tahun 1999 Tentang Hak Asasi Manusia. Jakarta

KOMPAS, (2010) :http://treshadiwijoyo.wordpress.com/2013/10/25/diskriminasi-dalampendidikan) 
Rachmat, C dan Suherdi, D. (1999). Evaluasi Pengajaran. Departemen Pendidikan dan Kebudayaan Direktorat Jenderal Pendidikan Tinggi Proyek Pendidikan Guru Sekolah Dasar

Risfaisal. (2013). Strategi Pembelajaran. Fakultas Keguruan dan Ilmu Pendidikan Universits Muhammadiyah Makassar

Ritzer, G. (2010). Sosiologi Ilmu pengetahuan Berparadigma Ganda. RajaGrafindo Persada : Jakarta

Soekanto, S. (1982). Sosiologi Suatu Pengantar. RajaGrafindo Persada: Jakarta

Soelaeman, M. (2008). Ilmu Sosial Dasar. Refika Aditama: Bandung.

Soekanto, Soerjono. (2009). Sosiologi Keluarga. Rineka Cipta : Jakarta

Sudijono, A. (1996). Pengantar Evaluasi Pendidikan. RajaGrafindo Persada: Jakarta

Suparlan, (2013). Manajemen Berbasisi Sekolah. Bumi Aksara: Jakarta

Theodorson \& Theodorson,dkk. (1979) :http://etyulia.blogspot.com/2012/03/

makalah־diskriminasi.html) 